\title{
PENGELOLAAN AIR LIMBAH DOMESTIK DI DKI JAKARTA
}

\author{
Oleh : \\ Nusa Idaman Said \\ Pusat Teknologi Lingkungan, Badan Pengkajian dan Penerapan Teknolgi (BPPT)
}

\begin{abstract}
Water pollution problem caused by household waste water in the region of DKI Jakarta, and more made worse by affecting of expanding settlement area in buffer zone around Jakarta which without provided with waste water facilities, so that all waste water thrown to public channel and finally flowing into river bodies in region of DKI Jakarta.

To overcome the mentioned above Government of Province DKI Jakarta have released Regulation of Governor Province Special District Capital of Jakarta Number 122 Year 2005 About Management Of Domestic Water Waste In Province Special District Capital Of Jakarta.

According To Regulation Of Governor of DKI Jakarta Number 122 Year 2005 Section 7 express that house building and non house building is obliged to manage domestic waste water before discharge to public channel or drainage.

Planning of domestic waste water treatment installation which represent environmental utilities or building represent conditions in course of publication of Permit Directing Of Usage Of Land;Ground (SIPPT), Plan Arrange Situation Building ( RTLB), Permission Found Building (IMB), and awaking up of domestic waste water treatment installation represent conditions in course of publication of Permit of Building Usage (IPB) and Elegibility Use Building (KMB), and also licensing of operational of institution in charge related to such operational.
\end{abstract}

Kata Kunci : Air limbah domestik, air limbah rumah tangga, pengelolaan.

\section{PENDAHULUAN}

\subsection{Masalah Pencemaran Air Di DKI Jakarta}

Dengan semakin besarnya laju perkembangan penduduk dan industrialisasi di Jakarta, telah mengakibatkan terjadinya penurunan kualitas lingkungan. Padatnya pemukiman dan kondisi sanitasi lingkungan yang buruk serta buangan industri yang langsung dibuang ke badan air tanpa proses pengolahan telah menyebabkan pencemaran sungai-sungai yang ada di Jakarta, dan air tanah dangkal di sebagian besar daerah di wilayah DKI Jakarta, bahkan kualitas air di perairan teluk Jakartapun sudah menjadi semakin buruk.

Air limbah kota-kota besar di Indonesia khususnya Jakarta secara garis besar dapat dibagi menjadi tiga yaitu pertama adalah air limbah industri, kedua adalah air limbah domestik yakni yang berasal dari buangan rumah tangga, dan yang ke tiga yakni air limbah dari perkantoran dan pertokoan (daerah kemersial). Saat ini selain pencemaran akibat limbah industri, pencemaran akibat limbah domestikpun telah menunjukkan tingkat yang cukup serius. Di Jakarta misalnya, sebagai akibat masih minimnya fasilitas pengolahan air buangan kota (sewerage system) mengakibatkan tercemarnya badan - badan sungai oleh air limbah domistik, bahkan badan sungai yang diperuntukkan sebagai bahan baku air minumpun telah tercemar pula. Dari hasil penelitian yang dilakukan oleh Dinas Pekerjaan Umum (PU) DKI Jakarta bersama-sama dengan Tim JICA (1990), jumlah unit air buangan dari buangan rumah tangga per orang per hari adalah 118 liter dengan konsentrasi BOD ratarata $236 \mathrm{mg} / \mathrm{lt}$ dan pada tahun 2010 nanti diperkirakan akan meningkat menjadi 147 liter dengan konsetrasi BOD rata-rata $224 \mathrm{mg} / \mathrm{tt}$.

Jumlah air buangan secara keseluruhan di DKI Jakarta diperkirakan sebesar 1.316.113 $\mathrm{M} 3 /$ hari yakni untuk air buangan domistik 1.038.205 M3/hari, buangan perkantoran dan daerah komersial $448.933 \mathrm{M} 3 /$ hari dan buangan industri 105.437 M3/hari. Dari hasil studi tersebut dapat diketahui bahwa untuk wilayah Jakarta, dilihat dari segi jumlah, air limbah domestik (rumah tangga) memberikan kontribusi terhadap pencemaran air sekitar $75 \%$, air limbah perkantoran dan daerah komersial $15 \%$, dan air limbah industri hanya sekitar $10 \%$. Sedangkan dilihat dari beban polutan organiknya, air limbah rumah tangga sekitar $70 \%$, air limbah perkantoran $14 \%$, dan air limbah industri memberikan kontribusi $16 \%$. Dengan demikan air limbah rumah tangga dan air limbah 
perkantoran adalah penyumbang yang terbesar terhadap pencemaran air di wilayah DKI Jakarta.

Masalah pencemaran oleh air limbah rumah tangga di wilayah DKI Jakarta lebih diperburuk lagi akibat berkembangnya lokasi pemukiman di daerah penyangga yang ada di sekitar Jakarta, yang mana tanpa dilengkapi dengan fasilitas pengolahan air limbah, sehingga seluruh air limbah dibuang ke saluran umum dan akhirnya mengalir ke badan-badan sungai yang ada di wilayah DKI Jakarta.

Untuk mengatasi hal tersebut di atas Pemerintah Provinsi DKI Jakarta telah mengeluarkan Peraturan Gubernur Propinsi Daerah Khusus Ibukota Jakarta Nomor 122 Tahun 2005 Tentang Pengelolaan Air Limbah Domestik Di Propinsi Daerah Khusus Ibukota Jakarta.

Menurut Peraturan Gubernur Nomor 122 tahun 2005 Bab V pasal 7 tersebut telah mewajibkan untuk mengolah air limbah domestik sebelum dibuang kesaluran umum. Bangunan rumah tinggal atau bangunan non rumah tinggal wajib mengelola air limbah domestik (black water maupun grey water) sebelum dibuang ke saluran umum/drainase. Bangunan rumah tinggal dan atau bangunan usaha/ jasa/ industri yang telah dibangun dan belum memiliki instalasi pengelolaan air limbah domestik yang memenuhi syarat baku mutu air limbah, wajib memperbaiki dan atau membangun instalasi pengolahan air limbah domestik.

\section{STRATEGI PENGELOLAAN AIR LIMBAH DOMESTIK DI PROPINSI DKI JAKRTA}

\subsection{Azas, Tujuan Dan Sasaran Pengelolaan Air Limbah Domestik}

Untuk mengatasi masalah pencemaran air di wilayah DKI Jakarta sudah sangat perlu untuk membangun fasilitas pengolahan air limbah perkotaan yang memadai. Saat ini yang sering dituding sebagai biang pencemaran lingkungan adalah pihak industri baik industri besar, menengah maupun industri kecil. Dan untuk industri telah diwajibkan untuk mengolah air limbahnya sebelum dibuang ke perairan umum sampai standar kualitas yang disyaratkan. Sedangkan untuk air limbah domestik, perkantoran dan daerah komersial yang kontribusi pencemaran mencapai sekitar $80 \%$ dari total sumber pencemaran air di DKI Jakarta hanya sekitar $3 \%$ yang telah diolah (PD PAL Jaya, 1996).

Dengan demikian jika strategi penanggulangan pencemaran air hanya dititikberatkan pada air limbah industri saja maka masalah pencemaran air di DKI Jakarta akan terus berlajut karena sumber pencemarnya yang paling utama yakni limbah domestik, perkantoran dan limbah daerah komersial belum dilakukan upaya penanggulangan secara sistematis.

Berdasarkan kondisi pencemaran kualitas air di wilayah DKI Jakarta, Pemerintah Propinsi DKI Jakarta telah mengeluarkan Peraturan Gubernur Provinsi Daerah Khusus Ibukota Jakarta Nomor 122 Tahun 2005 tentang Pengelolaan Air limbah Domestik di Provinsi Daerah Ibukota Jakarta.

Bersadarkan peraturan gubernur tersebut di atas, pengelolaan Air Limbah Domestik diselenggarakan dengan asas tanggung jawab pemerintah, asas berkelanjutan, asas hak dan kewajiban masyarakat, bertujuan untuk mencegah dan sekaligus menanggulangi pencemaran tanah dan air tanah akibat pembuangan air limbah domestik (black water maupun grey water) yang tidak memenuhi Baku Mutu Air Limbah.

\subsection{Sasaran Pengelolaan Air Limbah Domestik}

Sesuai Peraturan Gubernur Nomor 122 tahun 2005, sasaran pelaksanaan pengelolaan air limbah domestik di DKI Jakarta adalah :

a. Terbangunnya instalasi pengolahan air limbah domestik baik pada bangunan baru maupun bangunan lama, sesuai dengan tipologi, tata letak bangunan, jenis penggunaan bangunan dan klasifikasi volume air limbah.

b. Terbangunnya secara bertahap jejaring prasarana dan sarana sanitasi lingkungan bagian-bagian kota sesuai dengan Rencana Jaringan Sanitasi Kota.

c. Terpenuhinya Baku Mutu Air Limbah Domestik secara bertahap.

d. Meningkatnya kinerja industri jasa konstruksi di bidang peralatan dan perlengkapan pengolahan air limbah.

\subsection{Ruang Lingkup Pengelolaan Air Limbah Domestik}

Ruang lingkup pengelolaan air limbah domestik di DKI Jakarta adalah:

a. Arahan penjabaran Rencana Tata Ruang Wilayah ke dalam Rencana Induk Sanitasi Lingkungan.

b. Cara pengolahan air limbah domestik skala kota, kawasan, bangunan tinggi dan bangunan individual, baik bangunan baru maupun bangunan lama. 
c. Arahan pembinaan industri jasa konstruksi di bidang perlengkapan dan peralatan pengolahan air limbah domestik.

d. Koordinasi perencanaan, pelaksanaan, pengendalian dan pengawasan implementasi kebijakan pengelolaan air limbah, termasuk kegiatan diseminasi kebijakan bagi aparat dan sosialisasi kepada berbagai unsur masyarakat dan dunia usaha.

\subsection{Rencana Induk Sanitasi Lingkungan}

Penyusunan Rencana Induk Sanitasi Lingkungan di wilayah Provinsi DKI Jakarta meliputi beberpa hal yaitu :

(1) Instansi yang membidangi perencanaan kota dan Instansi yang membidangi pembangunan prasarana sanitasi lingkungan menjabarkan Rencana Tata Ruang Wilayah ke bentuk Rencana Induk Sanitasi Lingkungan secara hirarkhi.

(2) Rencana Induk Sanitasi Lingkungan sebagaimana dimaksud di atas mengambarkan kawasan pengelolaan air limbah domestik perpipaan secara terpusat, kawasan pengelolaan air limbah komunal dan semikomunal serta kawasan individual.

(3) Rencana Induk Sanitasi Lingkungan sebagaimana dimaksud pada ayat (1) disajikan pada Peta Skala $1: 50.000$ yang selanjutnya akan menjadi kelengkapan peraturan gubernur tersebut.

Secara garis besar rencana induk sanitasi lingkungan untuk pengelolaan air limbah domestik di DKI Jakatra berdasarkan pembagian wilayah pengelolaan air limbah secara jaringan perpipaan terpusat, wilayah dengan pengelolaan sistem IPAL semi komunal atau komunal, serta wilayah pengelolaan air limbah domestik dengan sistem IPAL individual dapat dilihat seperti paga Gambar 1.

Berdasarkan pada gambar tersebut di atas maka salah alternatif pengelolaan air limbah di DKI Jakarta dilakukan dengan cara menggolongkan menjadi tiga wilayah bagian yakni wilayah dengan keadatan penduduk tinggi (Area A) dimana pengelolaan air limbah domestik dilakukan dengan sistem jaringan perpipaan secara terpusat, wilayah dengan kepadatan penduduk sedang (Area B) dilakukan dengan cara pengolahan secara semi komunal atau secara konunal dan wilayah dengan kepadatan penduduk rendah (Area $\mathrm{C}$ ) dilakukan dengan cara pengolahan ditempat (On site treatment) secara individual.

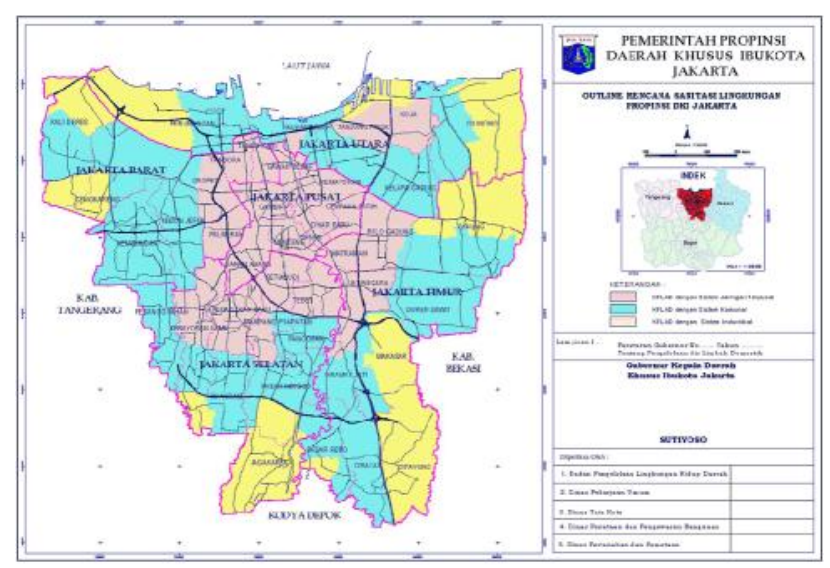

Gambar 1: Rencana pengembangan zona pengelolaan air limbah domistik di wilayah DKI Jakarta.

\subsubsection{Wilayah Dengan Kepadatan Penduduk Tinggi (Area A)}

Yaitu wilayah dengan kepadatan penduduk lebih besar dari 300 orang per hektar. Di wilayah ini prioritas pengelolaan air limbah domestik harus dilakukan dengan cara sistem pengolahan terpusat yakni dengan sistem jaringan terpusat (sewerage System) sampai mencapai baku mutu seperti yang ditetapkan di dalam peraturan gubernur DKI Jakarta Nomor 122 tahun 2005.

\subsubsection{Wilayah Dengan Kepadatan Penduduk Sedang (Area B)}

Yakni wilayah dengan kepadatan penduduk antara $100 \mathrm{~s} / \mathrm{d} 300$ orang per hektar. Di wilayah ini prioritas pengelolaan air limbah domestik dilakukan dengan cara pengolahan sistem semi komunal atau sistem komunal sampai mencapai baku mutu seperti yang ditetapkan di dalam peraturan gubernur DKI Jakarta Nomor 122 tahun 2005.

\subsubsection{Wilayah dengan kepadatan Penduduk Rendah (Area C)}

Yang dimaksud dengan wilayah dengan kepadatan penduduk rendah yakni wilayah dengan kepadatan penduduk tidak melebihi 100 orang per hektar. Di Wilayah ini pengelolaan air limbah domestik dilakukan dengan cara pengolahan ditempat (On Site Treatment) atau Individual. Seluruh air limbah domestik yang berasal dari kamar mandi, dapur dan air cucian dan toilet diolah dengan IPAL individual. 


\subsection{Pengelolaan Air Limbah Domestik}

Berdasarkan Peraturan Gubernur DKI Jakarta Nomor 122 Tahun 2005 Pasal 7 menyatakan :

(1) Bangunan rumah tinggal dan bangunan non rumah tinggal wajib mengelola air limbah domestik sebelum dibuang ke saluran umum/drainase kota.

(2) Perencanaan instalasi air limbah domestik yang merupakan utilitas lingkungan atau bangunan merupakan persyaratan dalam proses penerbitan Surat ljin Penunjukan Penggunaan Tanah (SIPPT), Rencana Tata Letak Bangunan (RTLB), ljin Mendirikan Bangunan (IMB), dan terbangunnya instalasi air limbah domestik merupakan persyaratan dalam proses penerbitan Surat ljin Pengunaan Bangunan (IPB) dan Kelayakan Menggunakan Bangunan (KMB), serta perijinan operasional dari instansi yang berwenang terkait dengan operasional dimaksud.

Sedangkan kewajiban untuk mengolah air limbah domestik sampai baku mutu yang telah ditetapkan sebelum dibuang ke perairan atau saluran umum dinyatakan dalam Pasal 8 sebagai berikut :

(1) Bangunan rumah tinggal dan non rumah tinggal yang telah dibangun dan belum memiliki instalasi pengelolaan air limbah domestik yang memenuhi syarat baku mutu air limbah, wajib memperbaiki dan atau membangun instalasi pengolahan air limbah domestik.

(2) Prosedur dan Panduan Teknik Penyempurnaan Instalasi Pengolahan Air Limbah Domestik sebagaimana dimaksud ayat (1) ditetapkan oleh Instansi yang bertanggung jawab dalam pengelolaan lingkungan hidup.

(3) Penyusunan Prosedur dan Panduan Teknik sebagaimana dimaksud pada ayat (2) dilakukan melalui koordinasi instansional dan masyarakat serta dunia usaha.

Untuk pengelolaan air limbah domestik di wilayah atau kawasan permukiman dengan kemampuan ekonomi terbatas merupakan tanggung jawab pemerintah melalui instansi yang ditunjuk bersama-sama dengan masyarakat, dinyatakan dalam pasal 9 sebagai berikut :
(1) Instansi yang bertanggung jawab dalam bidang perumahan bersama instansi terkait lainnya yang bertanggung jawab dalam bidang pengelolaan air limbah wajib membangun instalasi pengolahan air limbah domestik bersama masyarakat pada kawasan permukiman tertentu yang kemampuan ekonomi masyarakatnya terbatas

(2) Penyusunan kriteria dan pedoman penetapan kawasan tertentu sebagaimana dimaksud pada ayat (1) dilaksanakan oleh instansi yang bertanggung jawab dalam perencanaan kota bersama instansi terkait lainnya yang bertanggung jawab dalam bidang pengelolaan lingkungan hidup.

\subsection{Persyaratan Teknis Pengolahan Air Limbah Domestik.}

Berdasarkan Peraturan Gubernur DKI Jakarta Nomor 122 Tahun 2005, persyaratan teknis pengolahan air limbah domestik serta baku mutu air olahan yang boleh dibuang ke saluran umum dinyatakan dalam psal 10 dan pasal 11 sebagai berikut :

\section{Pasal 10:}

(1) Perancangan instalasi pengolahan air limbah domestik didasarkan pada besaran populasi penghuni bangunan dan jenis peruntukan bangunan.

(2) Teknis pengaturan pengolahan air limbah domestik sebagaimana dimaksud pada ayat (1) meliputi sistem pengolahan air limbah secara biologis, baik proses biomasa tersuspensi maupun proses biomasa melekat.

Pasal 11:

(1) Pengolahan air limbah domestik sebagaimana dimaksud dalam Pasal 10 ayat (2) meliputi jenis pengolahan individual, semi komunal dan komunal di kawasan pembangunan baru, kawasan perbaikan lingkungan, kawasan pemugaran dan kawasan peremajaan.

(2) Pengolahan air limbah sebagaiman dimaksud pada ayat (1) harus memenuhi ketentuan tentang Baku Mutu Air Limbah Domestik dan mengacu pada Pedoman Umum tentang sistem pengolahan air limbah domestik. 
(3) Air Limbah yang akan dibuang ke saluran umum kota wajib memenuhi ketentuan tentang Baku Mutu Air Limbah Domestik .

(4) Penerapan sistem pengolahan air limbah mengacu pada Pedoman Umum Tentang Sistem Pengolahan Air Limbah sebagaimana tercantum pada Gambar 2.1. (Lampiran IV Pergub DKI Jakarta No.122 Th. 2005).

Di dalam Pergub DKI Jakarta No. 122 TH. 2005, pada hakekatnya di dalam melakukan pengolahan air limbah domestik tidak mengharuskan menggunakan salah satu teknologi tertentu, yang menjadi acuan adalah kualitas air olahan harus memenuhi baku mutu seperti yang telah ditetapkan.(Tabel1).

Panduan teknis pengolahan air limbah di dalam Lampiran PERGUB DKI Jakarta Nomor 122 Tahun 2005 dimaksudkan sebagai panduan bagi masyarakat yang akan membangun instalasi pengolahan air limbah domestik. Di dalam panduan teknis tersebut menjelaskan beberapa jenis teknologi yang banyak digunakan untuk pengolahan air limbah domestik serta kriteria perencanaan dan kriteria operasional agar didapatkan hasil pengolahan air limbah domestik yang baik.

Tabel 1 : Baku Mutu Limbah Cair Domestik Di DKI Jakarta berdasarkan Peraturan Gubernur Provinsi DKI Jakarta Nomor 122 Tahun 2005

\begin{tabular}{|l|c|c|c|}
\hline PARAMETER & SATUAN & $\begin{array}{c}\text { INDIVIDUAL } \\
\text { / RUMAH } \\
\text { TANGGA }\end{array}$ & KOMUNAL \\
\hline $\mathrm{pH}$ & - & $6-9$ & $6-9$ \\
\hline $\mathrm{KMnO}_{4}$ & $\mathrm{Mg} / \mathrm{L}$ & 85 & 85 \\
\hline $\mathrm{TSS}$ & $\mathrm{Mg} / \mathrm{L}$ & 50 & 50 \\
\hline Amoniak & $\mathrm{Mg} / \mathrm{L}$ & 10 & 10 \\
\hline $\begin{array}{l}\text { Minyak \& } \\
\text { Lemak }\end{array}$ & $\mathrm{Mg} / \mathrm{L}$ & 10 & 20 \\
\hline $\begin{array}{l}\text { Senyawa Biru } \\
\text { Metilen }\end{array}$ & $\mathrm{Mg} / \mathrm{L}$ & 2 & 2 \\
\hline COD & $\mathrm{Mg} / \mathrm{L}$ & 100 & 80 \\
\hline BOD & $\mathrm{Mg} / \mathrm{L}$ & 75 & 50 \\
\hline
\end{tabular}

\subsection{Pembinaan Dan Pengawasan}

Pasal 12

(1) Instansi yang bertanggung jawab dalam bidang pengelolaan lingkungan hidup melaksanakan koordinasi instansional pengelolaan air limbah yang menjadi kewajiban pemerintah.
(2) Instansi yang bertanggung jawab dalam bidang industri dan perdagangan bersama asosiasi perusahaan sejenis melakukan program pembinaan bagi sektor jasa konstruksi bidang instalasi pengolahan air limbah domestik.

(3) Instalasi pengolahan air limbah domestik yang ditawarkan pemegang merk kepada masyarakat harus memiliki sertifikat yang menyatakan tingkat kemampuan instalasi memenuhi baku mutu air limbah domestik.

(4) Pernyataan tingkat kemampuan instalasi sebagaimana dimaksud pada ayat (3) diterbitkan oleh lembaga yang berwenang melakukan sertifikasi.

\section{Pasal 13}

(1) Instansi yang berwenang dalam perizinan bangunan, melakukan pengawasan konstruksi instalasi pengolahan air limbah domestik yang dibangun ditempat.

(2) Instansi yang bertanggung jawab dalam pengelolaan lingkungan hidup melakukan pengawasan kualitas hasil pengolahan air limbah domestik.

(3) Walikota dan Bupati melaksanakan tugas pengendalian dan pengawasan pelaksanaan peraturan ini di wilayah masing-masing;

\subsection{Hak, Kewajiban Dan Peran Serta Masyarakat}

\section{Hak Masyarakat :}

\section{Pasal 14}

Dalam Kegiatan pengelolaan air limbah domestik masyarakat berhak :

(1) Berperan serta dalam proses perencanaan pengelolaan air limbah perpipaan, komunal dan semi komunal.

(2) Memperoleh informasi tentang kebijakan dan rencana pengembangan pengelolaan air limbah domestik.

(3) Melaksanakan kegiatan usaha dalam kegiatan jasa konstruksi dengan mengikuti / mematuhi peraturan perundangan yang berlaku.

\section{Kewajiban Masyarakat :}

\section{Pasal 15}

Dalam Kegiatan pengelolaan air limbah domestik masyarakat wajib : 
(1) Berperan serta dalam pembangunan instalasi pengelolaan air limbah domestik.

(2) Menaati rencana sanitasi lingkungan yang telah ditetapkan.

\section{Peran Serta Masyarakat :}

Pasal 16

Peran Serta Masyarakat dalam proses pelaksanan kebijakan pengelolaan air limbah domestik meliputi :

(1) Pemberian masukan dalam rangka penyusunan kebijakan Sanitasi Lingkungan Kawasan Tertentu.

(2) Pemberian informasi tentang pengidentifikasikan berbagai potensi dan masalah pembangunan, termasuk bantuan untuk memperjelas hak atas ruang di wilayah dan termasuk pula pelaksanaan tata ruang kawasan.

(3) Bantuan untuk pengembangan sanitasi lingkungan permukiman.

(4) Pemberian informasi, saran, pertimbangan atau pendapat dalam penyusunan Rencana sanitasi Lingkungan.

(5) Pengajuan keberatan terhadap rancangan Rencana Sanitasi Lingkungan.

(6) Kerjasama dalam penelitian dan pengembangan kebijakan sanitasi lingkungan.

(7) Lingkungan masyarakat rumah tangga wajib mendorong terciptanya kondisi lingkungan yang sehat dari pencemaran air limbah domestik.

\subsection{Sanksi Administrasi}

Pasal 17:

(1) Pelanggaran terhadap ketentuan yang diatur dalam peraturan ini dikenakan sanksi administrasi sesuai dengan peraturan yang berlaku.

(2) Sanksi administrasi sebagaimana dimaksud dalam ayat (1) bagi kegiatan yang berbentuk badan usaha adalah berupa pencabutan ijin usaha dan/atau kegiatan.

(3) Sanksi administrasi sebagaimana dimaksud dalam ayat (1) bagi kegiatan rumah tinggal adalah berupa penyegelan bangunan.

\section{SISTEM PENGOLAHAN AIR LIMBAH DOMESTIK INDIVIDUAL}

Berdasarkan survey di Jakarta tahun 1989, tiap orang rata-rata mengeluarkan beban limbah organik sebesar 40 gram BOD per orang per hari, yakni dari limbah toilet 13 gram per orang per hari dan dari limbah non toilet sebesar 27 gram BOD per orang per hari. Jika hanya air limbah toilet yang diolah dengan sistem tangki septik dengan efisiensi pengolahan $65 \%$, maka hanya $22,5 \%$ dari total beban polutan organik yang dapat dihilangkan, sisanya 77,5 \% masih terbuang keluar. Hal ini secara umum dapat diterangkan seperti pada Gambar 2. Untuk mengatasi masalah air limbah rumah tangga, salah satu cara adalah dengan merubah sistem pembuangan air limbah yang lama, yakni dengan cara seluruh air limbah rumah tangga baik air limbah toilet maupun air limbah non toilet diolah dengan unit pengolahan air limbah di tempat (on site treatment), selanjutnya air olahannya dibuang ke saluran umum. Jika efisiensi pengolahan "On site treatment " ratarata $90 \%$, maka hanya tinggal $10 \%$ dari total beban polutan yang masih terbuang keluar. Sistem pembuangan air limbah dengan sistem "on site treatmet "secara sederhana ditunjukkan seperti pada Gambar 3.

Salah satu teknologi pengolahan air limbah rumah tangga dengan sistem "On Site Treatment " adalah dengan menggunakan proses kombinasi biofilter anaerob dan aerob. Sistem ini dapat diaplikasikan untuk tiaptiap rumah tangga maupun semi komunal yakni beberapa rumah menggunakan satu unit alat pengolahan air limbah.

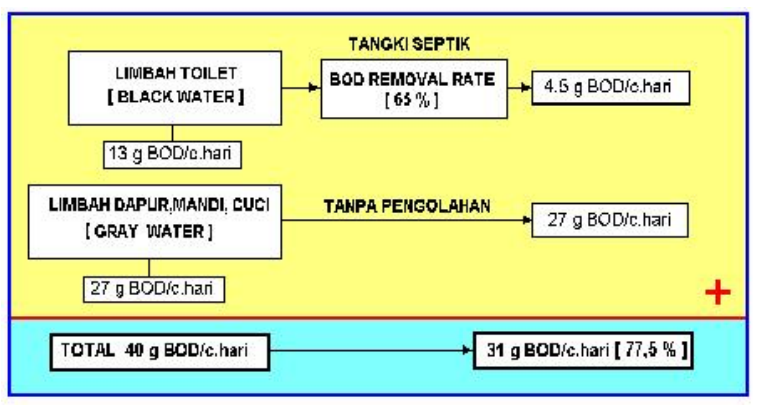

Gambar 2 : Efisiensi pembuangan air limbah rumah tangga dengan sistem On Site Treatment sederhana.

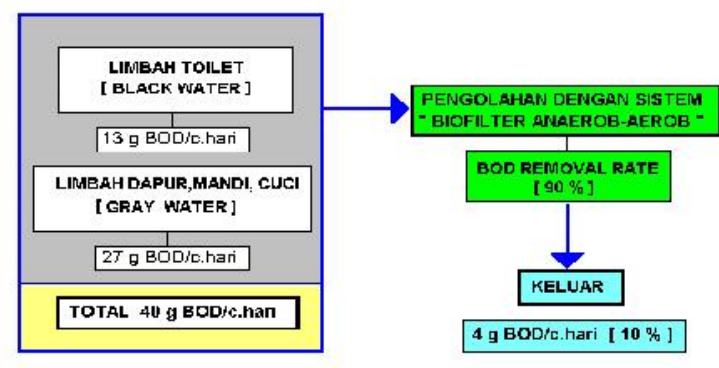

Gambar 3 : Efisiensi pengolahan air limbah rumah tangga secara "On Site Treatment". 


\subsection{Proses Pengolahan Air Limbah Domestik Dengan Sistem Biofilter Anaerob-Aerob Tipe Biotreat-10}

Unit IPAL Biotreat-10 merupakan unit instalasi pengolahan air limbah domestik individual dalam bentuk yang kompak. Seluruh air limbah domestik baik air limbah toilet maupun air limbah non toilet dialirkan ke unit IPAL melalui lubang pemasukan (inlet) masuk ke bak pengendapan atau bak pengurai awal. Air limpasan dari bak pengurai awal. Air limpasan dari bak pengendapan awal air dialirkan ke zona anaerob. Zona anaerob tersebut terdiri dari ruangan yang diisi dengan media dari bahan plastik sarang tawon untuk pembiakan mikroba. Pada zona anaerob air limbah mengalir dengan arah aliran dari atas ke bawah. Selanjutnya air limpasan dari zona anaerob mengalir ke zona aerob melalui lubang (weir).

Di dalam zona aerob tersebut air limbah dialirkan ke unggun media plastik sarang tawon sambil dihembus dengan udara. Air limbah dari zona aerob masuk ke bak pengendapan akhir melalui saluran yang ada di bagian bawah.

Air limbah yang ada di dalam bak pengendapan akhir tersebut sebagian disirkulasikan ke zona anaerob, sedangkan air limpasan dari bak pengendapan akhir tersebut merupakan air hasil olahan dan keluar melalui lubang pengeluaran. Selanjutnya air limpasan dari bak kontaktor dibuang ke saluran umum.

Setelah proses berjalan selama dua sampai empat minggu pada permukaan media sarang tawon akan tumbuh lapisan mikroorganisme, yang akan menguaraikan senyawa polutan yang ada dalam air limbah. Diagram proses IPAL dengan sistem biofilter anaerobaerob Tipe Biotreat-10 dapat dilihat seperti pada Gambar 4.

\subsubsection{Keunggulan}

Beberapa keunggulan proses pengolahan air limbah domestik dengan sistem kombinasi proses biofilter Anaerob-Aerob Tipe Biotreat-10 antara lain yakni :

- Efisiensi penghilangan BOD, COD dan padatan tersuspensi (SS) cukup tinggi, yakni lebih dari $90 \%$.

- Pengelolaannya sangat mudah.

- Biaya operasinya rendah.

- Dibandingkan dengan proses lumpur aktif, Lumpur yang dihasilkan relatif sedikit.

- Suplai udara untuk aerasi relatif kecil, untuk kapasitas 8-10 orang hanya membutuhkan listrik 40 watt.

- Dapat digunakan untuk air limbah dengan beban BOD yang cukup besar.
- Tahan terhadap perubahan beban pengolahan secara mendadak.

\subsubsection{Kriteria Perencanaan}

\begin{tabular}{|c|c|c|}
\hline PARAMETER & : & \\
\hline $\begin{array}{l}\text { Debit Air limbah } \\
\text { per kapita }\end{array}$ & : & 250 liter/org.hari \\
\hline BOD Inlet & : & $250 \mathrm{mg} / \mathrm{l}$ \\
\hline BOD Outlet & : & $50 \mathrm{mg} / \mathrm{l}$ \\
\hline $\begin{array}{l}\text { Efisiensi } \\
\text { Penurunan BOD }\end{array}$ & : & $80 \%$ \\
\hline $\begin{array}{l}\text { Waktu tinggal air } \\
\text { limbah di dalam } \\
\text { reaktor }\end{array}$ & & $\begin{array}{l}1-3 \text { hari. } \\
\text { Minimal } 1 \text { hari untuk proses } \\
\text { Aerobik atau kombinasi } \\
\text { Anaerobik-Aerobik. }\end{array}$ \\
\hline $\begin{array}{l}\text { Jenis air limbah } \\
\text { yang diolah }\end{array}$ & & $\begin{array}{l}\text { Toilet, kamar mandi, air } \\
\text { bekas cuci, dapur, wastafel } \\
\text { dll. }\end{array}$ \\
\hline $\begin{array}{l}\text { Proses Aerobik } \\
\text { atau Kombinasi } \\
\text { Proses } \\
\text { Anaerobik- } \\
\text { Aerobik }\end{array}$ & & $\begin{array}{l}\text { menurunkan polutan organik } \\
\text { (BOD, COD) dan Padatan } \\
\text { Tersuspensi (SS), amoniak, } \\
\text { sulfida, deterjen dll. }\end{array}$ \\
\hline Kendala & & $\begin{array}{l}\text { Sistem ini memerlukan luas } \\
\text { area tertentu sehingga tidak } \\
\text { sesuai untuk kawasan } \\
\text { dengan kepadatan } \\
\text { penduduk tinggi . }\end{array}$ \\
\hline
\end{tabular}

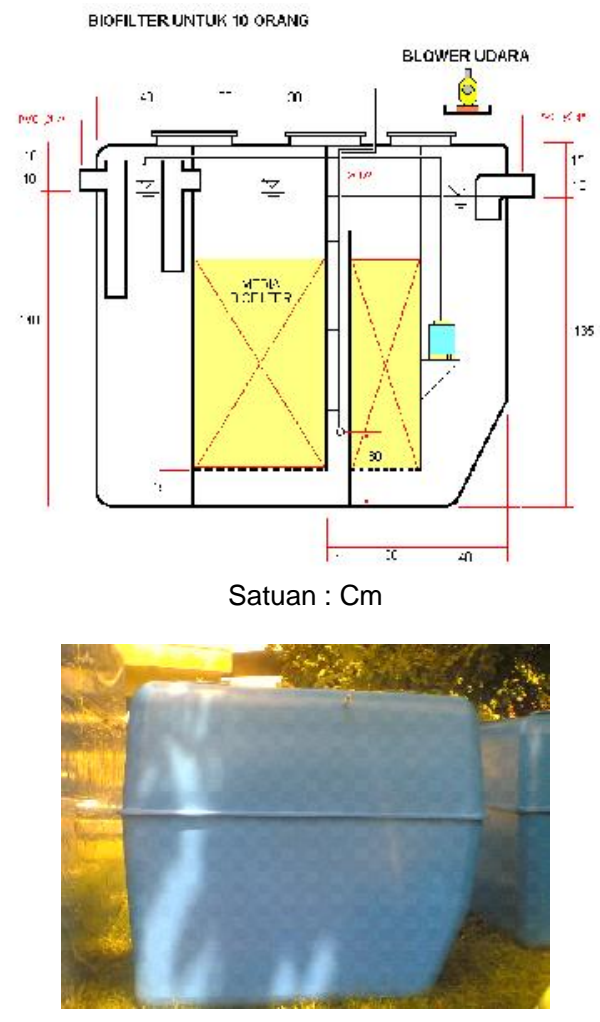

Gambar 4: Biofilter Untuk Air Limbah Domestik Biofilter Anaerob-Aerob Tipe Biotreat-10. Kapasitas 8 -10 Orang. 


\section{SPESIFIKASI ALAT :}

$\begin{array}{ll}\text { Jumlah Orang } & : 10 \text { orang } \\ \text { Debit perkapita } & : 250 \text { liter } \\ \text { Debit Air Limbah (Maksimum) } & : 2500 \text { liter/hari } \\ \text { Beban BOD } & : 0,625 \mathrm{~kg} \mathrm{BOD} \\ \text { per hari } & : 250 \mathrm{mg} / \mathrm{l} \\ \text { BOD Inlet } & : 25 \mathrm{mg} / \mathrm{l} \\ \text { BOD Outlet } & : 90 \% \\ \text { Efisiensi Penghilangan BOD }\end{array}$

Dimensi :

$\begin{array}{ll}\text { Panjang Efektif } & : 180 \mathrm{~cm} \\ \text { Lebar Efektif } & : 100 \mathrm{~cm} \\ \text { Kedalaman efektif } & : 140 \mathrm{~cm} \\ \text { Tinggi Ruang Bebas } & : 20 \mathrm{~cm} \\ \text { Volume Efektif } & : 2,52 \mathrm{~m}^{3} \\ \text { Waktu Tinggal rata-rata } & : 24 \mathrm{Jam} \\ \text { Diameter Inlet / Outlet } & : 4 \text { " } \\ \text { Volume Media Biofilter } & : 0,81 \mathrm{~m}^{3} \\ \text { Tipe media } & : \text { Media plastik } \\ \text { sarang tawon, Bioball. } & \end{array}$

\section{Blower :}

Kapasitas
Daya Listrik
Bahan
(FRP)

\section{Media Biofilter :}

$\begin{array}{ll}\text { Material } & : \text { PVC sheet } \\ \text { Ketebalan } & : 0,15-0,23 \mathrm{~mm} \\ \begin{array}{l}\text { Luas Kontak Spsesifik } \\ \text { m2/m3 }\end{array} & : 200-226 \\ \begin{array}{l}\text { Diameter lubang } \\ \text { Warna }\end{array} & \begin{array}{l}: 2 \mathrm{~cm} \times 2 \mathrm{~cm} \\ \text { transparan. }\end{array} \\ \begin{array}{l}\text { Berat Spesifik } \\ \text { Porositas Rongga }\end{array} & : 30-35 \mathrm{~kg} / \mathrm{m3} \\ & : 0,98\end{array}$

\subsubsection{Pemasangan IPAL}

- Air limbah toilet dialirkan langsung ke IPAL.

- Air limbah non toilet dialirkan ke bak kontrol, selanjutnya dilairkan ke IPAL.

- Lubang outlet IPAL harus berada di atas saluran penerima.

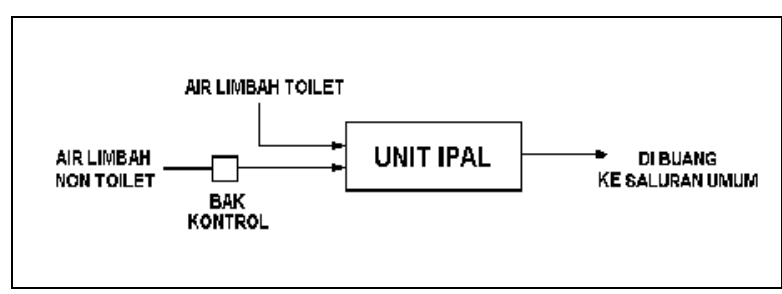

\section{HASIL UJI COBA}

Hasil Uji Coba Pengolahan Air Limbah Rumah Tangga Individual dengan sistem Biofilter Anaerob-Aerob :

Penghilangan BOD : 84,7 - $91 \%$

Penghilangan COD : 79,6 - 95,3\%

Penghilangan SS : $94,1-95 \%$

Penghilangan Ammonia $\left(\mathrm{NH}_{4}-\mathrm{N}\right): 89,3-89,8 \%$

Penghilangan Deterjen (Mbas) : $83-87 \%$

Penghilangan Phospat $\left(\mathrm{PO}_{4}\right)$ : 44,4 - 47,3\%

Dari hasil tersebut dapat dilihat bahwa pengolagan air limbah domestik dengan proses biofilter anaerob-aerob secara individual dapat memenuhi standar baku mutu sesuai dengan Peraturan Gubernur DKI Jakarta Nomor 122 tentang Pengelolaan air Limbah Domestik.

\section{DAFTAR PUSTAKA}

- -----, " Gesuidou Shissetsu Sekkei Shisin to Kaisetsu “, Nihon Gesuidou Kyoukai, 1984.

口 -----, "Pekerjaan Penentuan Standard Kualitas Air Limbah Yang Boleh Masuk Ke Dalam Sistem Sewerage PD PAL JAYA", Dwikarasa Envacotama-PD PAL JAYA, 1995.

a Abel. P.D. 1989. "Water Pollution Biology", Ellis Horwood Limited, Chichester, West Sussex, England.

- APHA (American Public Healt Association) 1985. "Standard Methods for the Examination of Water and Waste Water". Washington, D.C.1462 p.

- Fair, Gordon Maskew et.al., " Eements Of Water Supply And Waste Water Disposal", John Willey And Sons Inc., 1971.

- Gabriel Bitton. 1994. "Wastewater Microbiology", A John Wiley \& Sons, INC., New York.

a Gouda T., "Suisitsu Kougaku - Ouyouben", Maruzen kabushiki Kaisha, Tokyo, 1979.

a Hikaml, Sumiko., "Shinseki rosohou ni yoru mizu shouri gijutsu (Water Treatment with Submerged Filter)", Kougyou Yousui No.411, $12,1992$.

a JICA, The Studi On Urban Drainage and Wastewater Disposal Project in The City of Jakarta, Jica, 1990. 
- KPPL, Informasi Kualitas Lingkungan DKI Jakarta Tahun 1996, KPPL DKI Jakrta, 1997.

口 Metcalf And Eddy, " Waste Water Engineering", Mc Graw Hill 1978.

- Nusa Idaman, Teknologi Pengolahan Air Limbah Dengan Proses Biofilm Tercelup, JTL, DTL, BPPT, 2000.

- Peraturan Gubernur Propinsi Daerah Khusus Ibukota Jakarta Nomor 122 Tahun 2005 Tentang Pengelolaan Air Limbah Domestik Di Propinsi Daerah Khusus lbukota Jakarta
- Said, N.I., "Sistem Pengolahan Air Limbah Rumah Tangga Skala Individual Tangki Septik Filter Up Flow", Majalah Analisis Sistem Nomor 3, Tahun II, 1995.

口 Sueishi T., Sumitomo H., Yamada K., dan Wada Y., " Eisei Kougaku " (Sanitary Engineering), Kajima Shuppan Kai, Tokyo, 1987.

口 Viessman W, Jr., Hamer M.J., "Water Supply And Polution Control ", Harper \& Row, New York,1985.

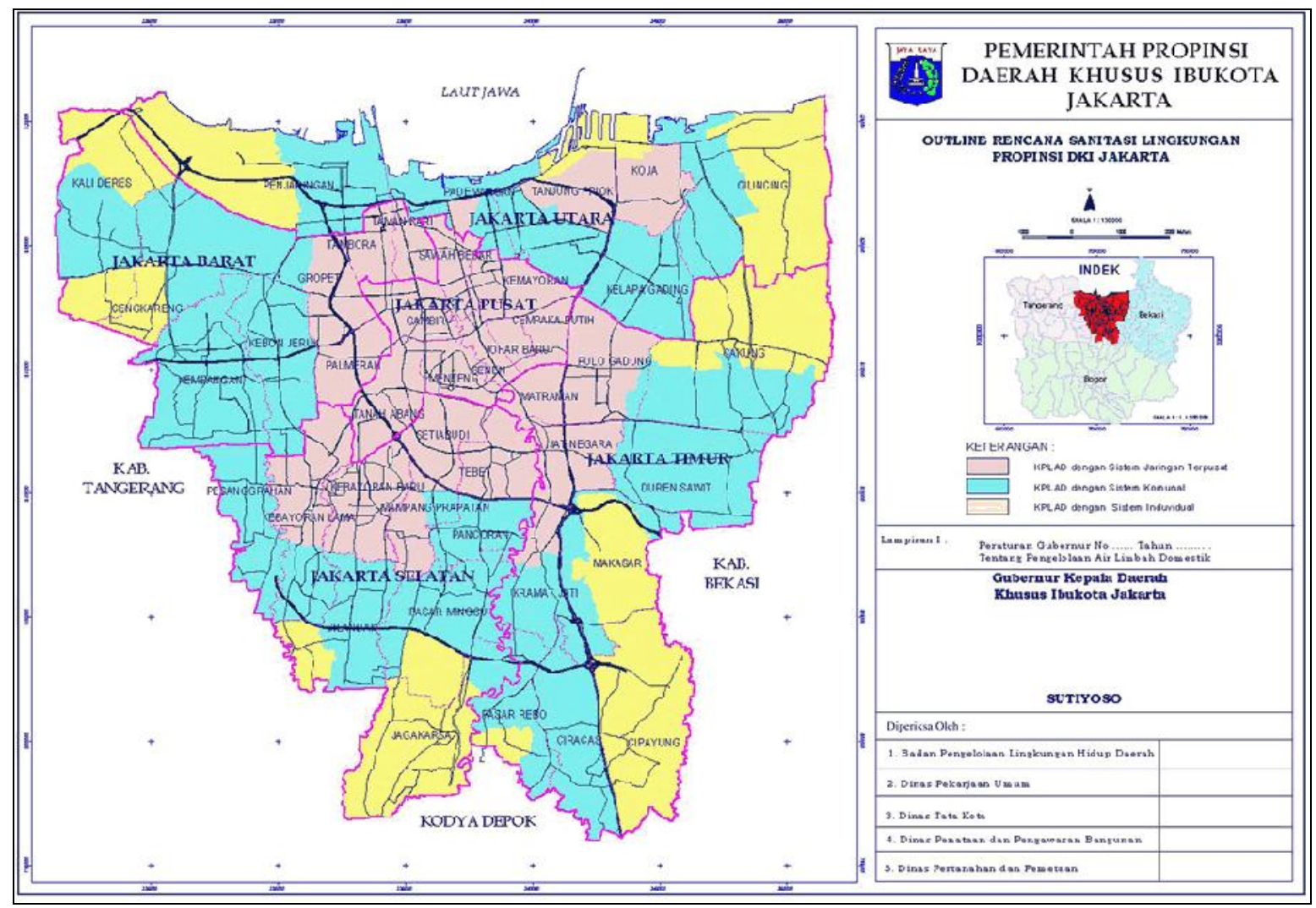

Gambar 1: Rencana pengembangan zona pengelolaan air limbah domistik di wilayah DKI Jakarta. 